DOI https://doi.org/10.30525/978-9934-26-047-6-18

\title{
ТЕОРЕТИКО-МЕТОДОЛОГІЧНІ ОСНОВИ ДОСЛІДЖЕННЯ ЕКОЛОГІЧНОЇ КОМПЕТЕНТНОСТІ МАЙБУТНІХ ЕКОЛОГІВ ПІД ЧАС НАВЧАННЯ У ЗВО
}

\author{
Демчук Л. I. \\ кандидат педагогічних наук, \\ дочент кафедри екологіі \\ Державний університет «Житомирська політехніка» \\ Кірейцева Г. В. \\ кандидат економічних наук, \\ дочент кафедри екологї \\ Державний університет «Житомирська політехніка» \\ м. Житомир, Украӥна
}

Сучасний світ характеризується різними проблемами, серед яких особливе місце займають питання екологічної безпеки. Найбільш вразливими серед міських районів $\epsilon$ міські поселення моноіндустріального типу, відмінною рисою яких є пряма залежність соціальноекономічного добробуту населення.

Система екологічної освіти в нашому регіоні досі роздроблена, безсистемна, концептуально слабка, здебільшого декларативна, а отже неефективна. Насправді вона покладається на ентузіастів, які часто працюють без належних ресурсів (інформативних, інструментальних та методичних). В результаті виникає розбіжність між розумінням того, що екологічна освіта та екологічні знання є ключовими складовими майбутніх фахівців, станом їх екологічної культури та розвитком екологічної компетентності [5, с. 16].

В контексті розвитку соціальних та природних відносин важливо навчити, перш за все, підростаюче покоління екологічно відповідальних поглядів на всі види спорту, освітніх та розвивальних заходів, заснованих на природничих знаннях та свідомості якості. Важливою частиною цього $є$ викладач, який має допомогти формуванню особистостей з екологічним та культурним досвідом. Отже, сам викладач природничого профілю повинен розвивати ідеї, думки та переконання щодо гармонійного союзу людини і природи, і власним прикладом надихати на екологічний розвиток здобувачів освіти. 
Важливою проблемою реалізації концепції безперервної екологічної освіти в Україні $є$ орієнтація на навчання та розвиток екологічних знань, починаючи 3 дошкільного віку без підтримки практичного досвіду в природоохоронній діяльності та екологічних навичок. Проаналізувавши існуючі літературні джерела та системи практичної діяльності, ми засвідчили недостатню підготовку до формування екологічної компетентності майбутніх фахівців (Г.Глухова, М.Колесник, Р.Мельниченко, Г.Науменко та ін. ).

Дослідження, які спрямовані на розвиток теоретичних аспектів екологічної компетентності особистості, закономірностей та принципів іiі формування, виявлених у працях В. Колонкової, Л. Липової, В. Маршицької, Р.Мельниченко, В.Пруцакової, Л.Руденко, В.Танська, С. Шмалей та ін.

Філософське розуміння єдності людини i природи подано у наукових працях В. Вернадського, О. Галєєва, О. Дорошко, М. Кисельова, В. Крисаченка, М. Мойсеєва, Ф. Нестеренка, Г. Платонов, І.Сафонов, І.Фролов та ін.

Значна роль у вирішенні проблеми відводиться дослідженням вчителів гуманітарних наук: Й. Коменського, М. Монтессорі, Ж. Руссо, Дж. Песталоцці, А. Дістерверга, О. Герда, а також домашніх учителів: К. Ушинського Г. Сковорода, Г. Ващенко, С. Русова, А. Макаренко, В. Сухомлинський, М. Стельмахович, які приділяли особливу увагу формуванню відповідального ставлення учнів до природи, суспільства, найближчого оточення.

Дослідження процесу екологічного виховання майбутніх фахівців належать формуванню та розвитку екологічної свідомості, екологічного світогляду, екологічної поведінки, відповідального ставлення, а також аспектів еколого-аксіологічних, організаційних характеристик процесу екологічного виховання у вищій школі. Проблемою підготовки майбутніх фахівців в різних аспектах займалися вчені: В.Бондаренко (формування готовності студентів до краєзнавчої роботи 3 дітьми); В.Іванцов (підготовка майбутніх фахівців до практичної діяльності в процесі вивчення спеціальних дисциплін); Я. Логвинова (формування екологічної компетентності майбутніх спеціалістів в процесі вивчення природничих дисциплін).

Отже, значна частина досліджень присвячена вивченню деяких відокремлених питань екологічної компетентності. Однак всебічне вивчення проблеми підготовки здобувачів освіти вищих навчальних закладів, особливо майбутніх фахівців, 3 акцентом на формування 
екологічних компетенцій все ще залишається поза увагою науковців та викладачів як теоретично, так і методологічно.

Мета статті - вивчення теоретико-методологічних основ формування екологічної компетентності майбутніх фахівців у процесі навчання у ЗВО.

В даний час терміни «компетентність», «екологічна компетентність», «професійна компетентність» в науковій та психолого-педагогічній літературі трактуються по-різному.

Щодо співвідношення понять компетенції та компетентності, ми погоджуємося 3 А. Хутірським, який стверджує, що компетентність включає сукупність взаємопов'язаних рис особистості (знань, умінь, навичок, способів діяльності), визначених відповідно до певного кола суб'єктів та процесів, які необхідні для якісної продуктивної діяльності, що стоїть за ними. Компетенція - володіння людиною відповідною компетентністю, що включає їі особисте ставлення до неї та суб'єкта діяльності [7, с. 66].

Сучасна екологічна освіта зазнає кардинальних змін, спрямованих на формування рис особистості, в основі яких лежить здатність свідомо застосовувати набуті теоретичні знання на практиці. Узагальнений набір цих якостей визначається поняттям «компетентність». Важливо також наголосити на необхідності тренувань особистості, яка має систему екологічних знань, набутих у процесі навчання, разом із навичками та вміннями адекватно функціонувати у відповідних життєвих ситуаціях, передбачати та прогнозувати наслідки своєї діяльності щодо змін у навколишньому середовищі.

Отже, ми компетентність розглядаємо як особистісну характеристику, яка поєднуватиме в собі знання, вміння, навички і відносини, які дозволяють особистості виконувати ті чи інші функції, спрямовані на досягнення мети в конкретній діяльності.

Слід зазначити, що крім поняття «екологічна компетентність», вчені використовують ті самі або подібні поняття, такі як: екологічна освіта, екологічна культура, екологічна свідомість, глобальний погляд на навколишнє середовище тощо.

Так, наприклад, екологічна вихованість $є$ комплексною властивістю особистості, яка характеризується наявністю і рівнем сформованості у неї екологічного світогляду, позитивної мотивації до непрагматичної взаємодії зі світом природи, а також умінням оцінювати і аналізувати наслідки тих чи інших дій людини в природі [3, с. 7]. Екологічна культура розуміється Г. Глуховою як складна категорія, інтегруючий комплекс якостей особистості, які знаходяться у відповідному 
співвідношенні та трансформуються через аксіологічні переконання в активну майбутню природоохоронну діяльність [2, с. 16].

Майбутній фахівець, як вважає Л.Юмашева, має володіти наступними ознаками екологічної компетентності: професійна діяльність, що забезпечує безпеку людей та охорону навколишнього середовища; навички професійної рефлексії; існування моральних цінностей та пріоритетів (прагнення до співчуття, толерантності, відповідальності) [8, c. 159].

Аналіз практики сучасної екологічної освіти здобувачів освіти у вишах дозволив виявити певне протиріччя, сутність якого полягає в тому, що формування екологічної компетентності має загальнопедагогічний, соціокультурний статус і вимагає комплексного підходу у виші, тоді як фактично реалізація завдань екологічної освіти звужена до предметоцентричного формату в рамках курсу екології, обмежується теоретичною підготовкою, відірваною від практично професійної, конкретної екологічної діяльності в професійній сфері та побуті. Як показує аналіз практики, в підготовці майбутніх фахівців до формування екологічної компетентності у ЗВО приділяється недостатньо уваги.

Таким чином, на основі аналізу наукової літератури з проблеми дослідження можна зробити висновок, що екологічна компетентність майбутніх екологів під час навчання у ЗВО є важливою рисою особистості, невід'ємною частиною їх професійної компетентності. Вона включає безліч екологічних знань, ідей, поглядів, переконань, ідеалів, моральних оцінок студентів щодо навколишнього середовища, природи загалом, які інтегровані в особисту систему екологічних цінностей, що визначають життя та діяльність майбутніх фахівців.

\section{Література:}

1. Ахметова М.X. Образование как средство формирования экологической компетентности молодёжи: Материалы II международной научно-практической конференции «Экологическое образование и экологическая культура населения». Пенза - Прага, 2014. C. 102-107.

2. Глухова Г.Г. Аксиологические основы формирования экологической культуры студентов высших учебных заведений. Автореф. дис ... канд. пед. наук: НПУ імені М. Драгоманова. Киев : 2008.23 с.

3. Мельниченко Р.К. Экологическая компетентность педагога как условие осуществления непрерывного экологического образования и 
воспитания. Научные записки КГПУ. Серия: Проблемы методики физико-математического и технологического образования. Кировоград: КГПУ. 2013. Вып. 4. Ч. 2. С. 271-275.

4. Методичні проблеми екології / Циганенко А.Я., Щербань М.Г., Жуков В.І., Бойчук Ю.Д. ті ін./ за ред. А.Я.Циганенка. - Харків: ХМУ, 2002. $163 \mathrm{c}$.

5. Олейник Н.Ю. Формирование экологической компетентности студентов техникума в процессе обучения информационным технологиям: учеб. дис ... канд. пед. Наук: / Олейник Н.Ю. - Хабаровск, 2005. $19 \mathrm{c}$.

6. Титаренко Л. М. Формування екологічної компетентності студентів біологічних спеціальностей університетів. Автореф. дис. .. канд.. пед. наук: 13.00.07. -К., 2007. - 20 с

7. Хуторской А.В. Технология проектирования ключевых и предметных компетенций. Инновации в общеобразовательном процессе. Сборник научных трудов. М.: ГНУ ИСМО РАО, 2006. С. 65-79.

8. Юмашева Л.В. Екологічна компетенція і екологічна компетентність як інтегрований результат екологічної освіти. Інтернетжурнал ICEЕ. 2012. № 7 (липень). С. 157-161. 